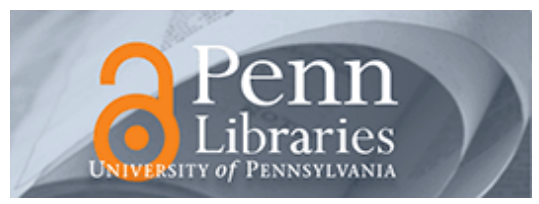

University of Pennsylvania

ScholarlyCommons

Departmental Papers (EES)

Department of Earth and Environmental

Science

November 2001

\title{
A Dendroctonus Bark Engraving (Coleoptera: Scolytidae) From A Middle Eocene Larix (Coniferales: Pinaceae): Early Or Delayed Colonization?
}

\author{
Conrad C. Labandeira \\ Smithsonian Institution \\ Ben A. LePage \\ University of Maryland \\ Arthur $\mathrm{H}$. Johnson \\ University of Pennsylvania, ahj@sas.upenn.edu
}

Follow this and additional works at: https://repository.upenn.edu/ees_papers

\section{Recommended Citation}

Labandeira, C. C., LePage, B. A., \& Johnson, A. H. (2001). A Dendroctonus Bark Engraving (Coleoptera:

Scolytidae) From A Middle Eocene Larix (Coniferales: Pinaceae): Early Or Delayed Colonization?. Retrieved from https://repository.upenn.edu/ees_papers/17

Reprinted from American Journal of Botany, Volume 88, Number 11, November 2001, pages 2026-2039.

This paper is posted at ScholarlyCommons. https://repository.upenn.edu/ees_papers/17

For more information, please contact repository@pobox.upenn.edu. 


\title{
A Dendroctonus Bark Engraving (Coleoptera: Scolytidae) From A Middle Eocene Larix (Coniferales: Pinaceae): Early Or Delayed Colonization?
}

\begin{abstract}
An engraving made by a scolytid bark beetle, assigned to the genus Dendroctonus of the tribe Tomicini, has been identified on a mummified, middle Eocene ( $45 \mathrm{Ma}$ ) specimen of Larix altoborealis wood from the Canadian High Arctic. Larix altoborealis is the earliest known species of Larix, a distinctive lineage of pinaceous conifers that is taxonomically identifiable by the middle Eocene and achieved a broad continental distribution in northern North America and Eurasia during the late Cenozoic. Dendroctonus currently consists of three highly host-specific lineages that have pinaceous hosts: a basal monospecific clade on Pinoideae (Pinus) and two sister clades that consist of a speciose clade associated exclusively with Pinoideae and six species that breed overwhelmingly in Piceoideae (Picea) and Laricoideae (Pseudotsuga and Larix). The middle Eocene engraving in L. altoborealis represents an early member of Dendroctonus that is ancestral to other congeneric species that colonized a short-bracted species of Larix. This fossil occurrence, buttressed by recent data on the phylogeny of Pinaceae subfamilies and Dendroctonus species, indicates that there was phylogenetically congruent colonization by these barkbeetle lineages of a Pinoideae + (Piceoideae + Laricoideae) host-plant sequence. Based on all available evidence, an hypothesis of a geochronologically early invasion during the Early Cretaceous is supported over an alternative view of late Cenozoic cladogenesis by bark beetles onto the Pinaceae. These data also suggest that host-plant chemistry may be an effective species barrier to colonization by some bark-beetle taxa over geologically long time scales.
\end{abstract}

\section{Keywords}

Canadian Arctic, coevolution, Dendroctonus, Eocene, Larix, Napartulik, Pinaceae, plant-insect associations, Scolytidae, Tomicini

\section{Comments}

Reprinted from American Journal of Botany, Volume 88, Number 11, November 2001, pages 2026-2039. 


\title{
A DENDRoctonus BARK ENGRAVING (COLEOPTERA: SCOLYTIDAE) FROM A MIDDLE EOCENE LARIX (Coniferales: Pinaceae): early or delayed COLONIZATION? ${ }^{1}$
}

\author{
Conrad C. Labandeira, ${ }^{2,4}$ Ben A. LePage, ${ }^{3}$ And \\ ARTHUR H. JOHNSON ${ }^{3}$

\begin{abstract}
${ }^{2}$ Department of Paleobiology, National Museum of Natural History, Smithsonian Institution, Washington, D. C. 20560 USA and Department of Entomology, University of Maryland, College Park, Maryland 20742 USA; and ${ }^{3}$ Department of Earth and Environmental Science, University of Pennsylvania, Philadelphia, Pennsylvania 10904 USA
\end{abstract}

\begin{abstract}
An engraving made by a scolytid bark beetle, assigned to the genus Dendroctonus of the tribe Tomicini, has been identified on a mummified, middle Eocene (45 Ma) specimen of Larix altoborealis wood from the Canadian High Arctic. Larix altoborealis is the earliest known species of Larix, a distinctive lineage of pinaceous conifers that is taxonomically identifiable by the middle Eocene and achieved a broad continental distribution in northern North America and Eurasia during the late Cenozoic. Dendroctonus currently consists of three highly host-specific lineages that have pinaceous hosts: a basal monospecific clade on Pinoideae (Pinus) and two sister clades that consist of a speciose clade associated exclusively with Pinoideae and six species that breed overwhelmingly in Piceoideae (Picea) and Laricoideae (Pseudotsuga and Larix). The middle Eocene engraving in L. altoborealis represents an early member of Dendroctonus that is ancestral to other congeneric species that colonized a short-bracted species of Larix. This fossil occurrence, buttressed by recent data on the phylogeny of Pinaceae subfamilies and Dendroctonus species, indicates that there was phylogenetically congruent colonization by these bark-beetle lineages of a Pinoideae + (Piceoideae + Laricoideae) host-plant sequence. Based on all available evidence, an hypothesis of a geochronologically early invasion during the Early Cretaceous is supported over an alternative view of late Cenozoic cladogenesis by bark beetles onto the Pinaceae. These data also suggest that host-plant chemistry may be an effective species barrier to colonization by some bark-beetle taxa over geologically long time scales.
\end{abstract}

Key words: Canadian Arctic; coevolution; Dendroctonus; Eocene; Larix; Napartulik; Pinaceae; plant-insect associations; Scolytidae; Tomicini.

The varied and often intimate associations among species of plants and insects are a major source for ecological diversity in much of the world and historically have provided a major role in structuring terrestrial ecosystems. A fundamental method in evaluating the dependency of insects on their vascularplant hosts is to assess the phylogenies of each component of these associated systems for congruence. These tests typically have been expressed as joint phylogenies of host and herbivore associates that may indicate (1) parallel, herbivore-for-host cladogenesis; (2) delayed, or sequential, radiation of insect herbivores on previously diversified plant hosts; (3) the deployment of a more complex pattern of "escape-and-radiate" coevolution whereby plants evolve antiherbivore strategies only to have them occasionally breached by insect herbivores, resulting in renewal of another cycle of defense and attack; or (4) looser, diffuse arrangements between plant and host that lack a demonstrably congruent pattern (Thompson, 1994;

\footnotetext{
${ }^{1}$ Manuscript received 4 January 2001; revision accepted 8 May 2001.

The authors thank Finnegan Marsh, who drafted Figs. 1, 10, and 11, and formatted Figs. 2-9; the staff of the National Museum of Natural History Library, who retrieved much-needed articles; the Polar Continental Shelf Project for field and logistical support; and Patrick Fields, Robert Rabaglia, Andrea Sequeira, Stephen Wood, and Scott Kelley who provided critical comment on previous drafts. The authors recognize that the conclusions reached herein are our own. Financial support for this research was provided from grants by the Walcott Fund of the Smithsonian Institution (C.C.L), the University of Pennsylvania Mellon Geobiology Initiative, the University of Pennsylvania Research Fund, and the Andrew W. Mellon Foundation (B.A.L, A.H.J). This is contribution no. 42 of the Evolution of Terrestrial Ecosystems Consortium at the National Museum of Natural History and contribution no. 031-00 of the Polar Continental Shelf Project.

${ }^{4}$ Author for reprint requests (e-mail: labandeira.conrad@nmnh.si.edu).
}

Schoonhoven, Jermy, and Van Loon, 1998; Labandeira, 2001). Such tests are almost always addressed by phylogenetic analyses of interacting extant representatives from both the plant and insect clades, but rarely calibrated to or informed by fossil occurrences. More unusual is the presence of fossil material that is sufficiently well preserved that identifiable insect damage can be linked to an equally identifiable plant host (Opler, 1973; Larew, 1986; Labandeira et al., 1994; Wilf et al., 2000). It is in this context that we present rare fossil wood engravings of an insect in a well-preserved Larix Miller stem (Pinaceae) of middle Eocene age from the Canadian High Arctic. The insect responsible for this damage is an unidentifiable bark beetle within the modern genus Dendroctonus Erichson (Scolytidae), whose modern relatives are economically destructive species that occur on North American conifers (Anderson, 1960).

Considerable progress relevant to this study has included advances in the systematics and phylogeny of the Pinaceae and its collateral and substituent lineages (Frankis, 1989; Farjon, 1990; Tsumura et al., 1995; Chaw et al., 1997; Xiao-Quan et al., 1997; Stefanovic et al., 1998), as well as an examination of the phylogeny and evolution of host-plant associations of the Scolytidae and the Pinaceae-feeding bark beetle, Dendroctonus, based on molecular systematic analyses (Kelley and Farrell, 1998; Sequeira, Normark, and Farrell, 2000). Given this background, the middle Eocene bark beetle gallery system described in this report provides relevant data for addressing four questions regarding the macroevolutionary history of the Pinaceae and one of their associated herbivore lineages. First, how old is the Pinaceae and Dendroctonus association? Sec- 


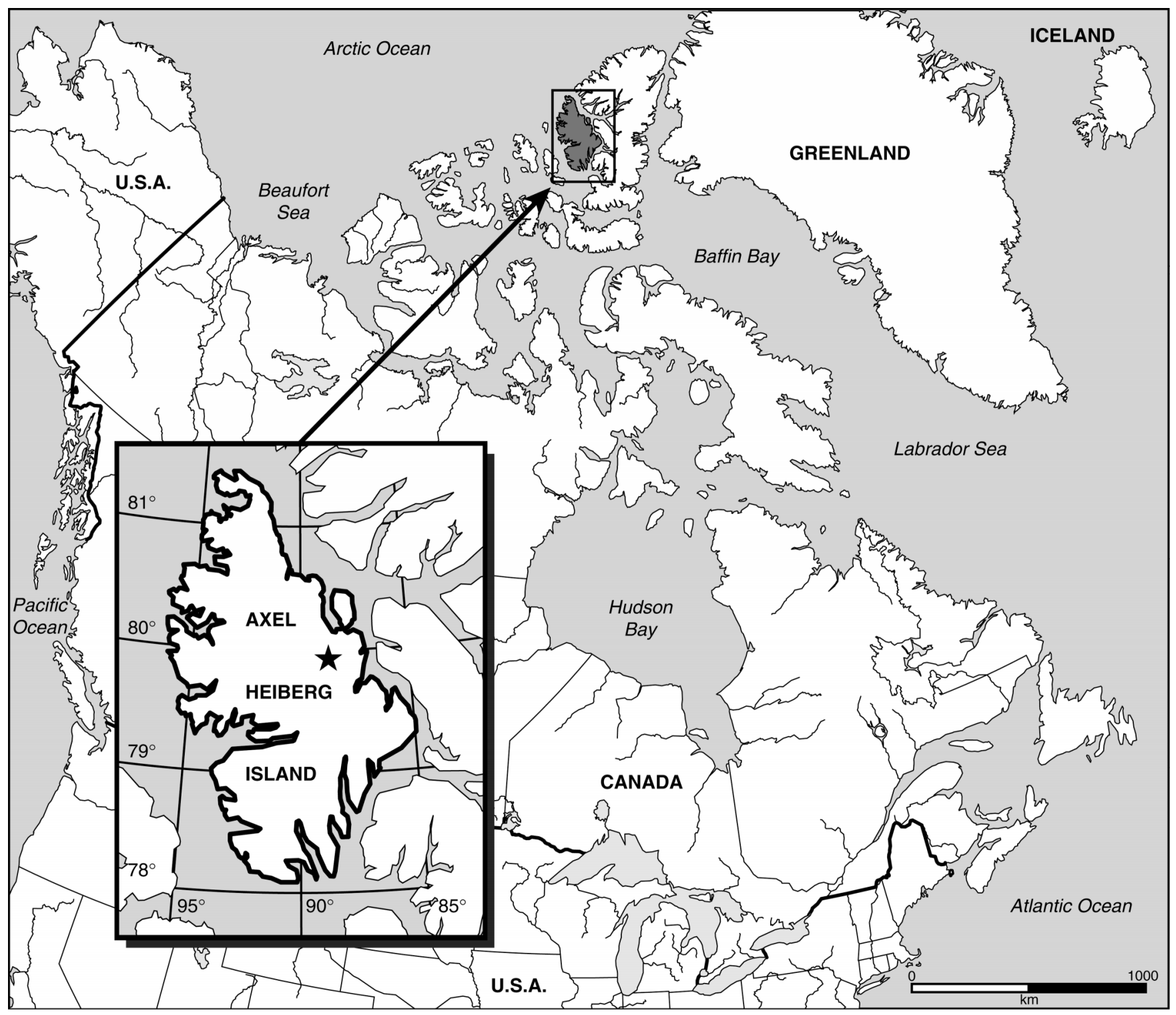

Fig. 1. Locality map of Axel Heiberg Island, Nunavut, Canada. The star (ఓ) designates the position of the Napartulik (Geodetic Hills locality) where the Larix $\log$ was found.

Figure abbreviations: $\mathrm{cg}=$ central gallery, $\mathrm{ft}=$ feeding tunnel, $\mathrm{lt}=$ larval tunnel, $\mathrm{pc}=$ pupal chamber, $\mathrm{sg}=$ secondary gallery.

ond, what was the likely colonization pathway of Larix species by Dendroctonus bark beetles? Third, which of the above four hypotheses for expressing the macroevolutionary patterns of plant-insect associations does the data support? And lastly, is there evidence for unusual avoidance of certain plant-hosts or for long-term faithful associations within this system? Most of these issues were broached by the important papers of Kelley and Farrell (1998) and Sequeira, Normark, and Farrell (2000), which provided important data on the evolution of host specialization in Dendroctonous bark beetles and their relatives.

\section{MATERIALS AND METHODS}

The fossil stem of Larix altoborealis LePage et Basinger containing the scolytid engraving was recovered from the middle Eocene Buchanan Lake Formation, the youngest and uppermost major unit of the Eureka Sound
Group. This formation is part of a sedimentary sequence ranging from Late Cretaceous (Campanian) to late Eocene (Priabonian) (Ricketts, 1986, 1991, 1994; LePage and Basinger, 1989). The middle Eocene age of this specimen corresponds to the Lutetian Stage (Eberle and Storer, 1999; Harrison et al., 1999), equivalent to the Uintan North American land mammal age, representing an interval from 41.3 to $47.5 \mathrm{Ma}$. The Buchanan Lake Formation occurs within the Sverdrup Basin on Axel Heiberg and Ellsmere islands along the northern margin of the Canadian Arctic Archipelago and is best exposed at Napartulik (Inuk for "the place of trees"), near Geodetic Hills on eastern Axel Heiberg Island (LePage and Basinger, 1991b), in a region corresponding to $79^{\circ} 55^{\prime} \mathrm{N}$ and $89^{\circ} 02^{\prime} \mathrm{W}$ (Fig. 1). This site prominently exposes the uppermost of the four members of the Buchanan Lake Formation, namely an upper lignitic and coal-bearing unit. This unit contains in situ leaf litter mats that have produced vegetative and reproductive organs of gymnospermous and angiospermous swamp forest and associated taxa, including needle fascicles, leaves, cones, seeds, and wood. These plants lived in a local floodplain basin 
and were rapidly buried by fluvial systems and debris flows originating from the ancestral Princess Margaret Mountain Range a few kilometers to the west (Ricketts, 1991). Rapid burial by coarse alluvial deposits resulted in the pristine morphological preservation observed in the fossils, through elimination or reduction of oxygen to the entombed plants, and thus prevented microbial decay (Ricketts and McIntyre, 1986; Basinger, McIver, and LePage, 1988). The paludal taxodiaceous taxa Metasequoia Hu et Cheng (dawn redwood) and Glyptostrobus Endlicher (Chinese swamp cypress) are preserved as megafossils. They were the dominant plants of this poorly drained swamp community, although Picea A. Dietrich (spruce), Larix (larch), Pseudolarix Gordon (golden larch) and Pinus L. (pine) were less abundant (LePage and Basinger, 1991a, b, 1995b; LePage, 2001). Tsuga (Endlicher) Carrière (hemlock), Keteleeria Carrière (fir), Chamaecyparis Spach (false cedar), Betula L. (birch), Carya Nuttall (hickory), Alnus P. Miller (alder), Cercidiphyllum Siebold ex Zuccarini (katsura), and several other unidentified woody dicotyledonous angiosperms were also present (LePage and Basinger, 1989, 1991a, b; Basinger, 1991; Greenwood and Basinger, 1994). This spectrum of plant taxa is supported by a palynofloral analysis of leaf litter and intervening silt and mudstone horizons at this site (McIntyre, 1991) and further reveals a more diverse spectrum of ferns and angiosperms. This suggests the presence of adjacent mixed woodland and shrubland, which is interpreted as having grown under a temperate to warm-temperate climate (Basinger, 1991). MidEocene continental climates were considerably milder than the climates of equivalent latitudes today (Wolfe, 1980), and pole-to-equator temperature gradients were the weakest recorded for the Cenozoic (Greenwood and Wing, 1995; Wilf and Labandeira, 1999).

The single unbranched specimen, consisting of original wood unaltered by mineral replacement (mummification), was extracted from the deposit by hand sawing an exposed stem and freeing a segment $12 \mathrm{~cm}$ in diameter and $\sim 24$ $\mathrm{cm}$ long. Sediment matrix, ranging in grain size from a fine sand to a silt, was removed from the insect engraving by applying distilled water containing thymol, with a soft no. 2 camelhair brush. No frass was observed in the tunnels or galleries, suggesting they were exposed to surrounding entombing sediment after postmortem removal of bark. Both direct floodlight illumination and low-angle fiberoptic lighting were used for photography and camera lucida drawings of the tunnel and gallery network. An Olympus SZH stereomicroscope (Olympus Optical, Tokyo, Japan) was used for all documentation in Figs. 2-8. The specimen is deposited in the Paleobotanical collections at the Canadian Museum of Nature at Ottawa, Canada, as specimen number CMN-51290.

\section{DESCRIPTION OF SPECIMEN}

Below we provide a description of the material with comments on its interpretation, taxonomic assignment, and the biology of extant relatives. Additional, more informative material is desirable to support this generic assignment. In this section, our discussion of the specimen is based on the orientation provided in Figs. 2-8, principally by the terms "right" and "left," and "upper" and "lower," which are determined with reference to the central gallery.

Structure of the engraving-The engraving is a complex gallery-and-tunnel network (excavated in the trunk) affecting the upper surface of the cambium, the phloem, and the lower surface of the bark. The bark exfoliated after death of the tree but previous to sediment entombment. This engraving consists of a linear, unbranched feeding tunnel $0.5 \mathrm{~cm}$ in diameter and $3.5 \mathrm{~cm}$ in length, as well as a central ovoidal gallery, from which major lateral tunnels originate whose long axes are ultimately oriented parallel (or longitudinal) to the wood grain. Twenty-one preserved branching tunnels emerge from one side only of the central ovoidal gallery and initially branch more or less perpendicularly, becoming progressively inclined distally toward the periphery of the engraving, and thus provide a distinctive radiating appearance. Four of these tunnels terminate into identifiable ovoidal expansions that are approximately twice the width of the mean tunnel width. Branching tunnels only occur from the upper half of the gallery network, a feature that is primary and not attributable to differential preservation (Figs. 3, 8). Several relict larval tunnels are discernible in the lower region (Figs. 3, 8), but do not appear to be associated with the above gallery system.

The central gallery is $2.7 \mathrm{~cm}$ long by $1.3 \mathrm{~cm}$ wide by 0.25 $\mathrm{cm}$ deep at the least and ovoidal and flat in shape. It exhibits some abraded edges, but in places there is distinct penetration into deeper cambial tissue, revealing active excavation (Figs. $2-4,8)$. The floor of the gallery is relatively planar, with fine striae paralleling the wood grain, and differing in texture from the general sapwood surface (Fig. 4). What may be a feeding and/or exit tunnel (Fig. 8, ft) emerges from the left side of the central gallery.

Major lateral tunnels are indicated in Figs. 2-4 and 8, shown emerging from the upper margin of the central gallery, initially perpendicular but subsequently parallel to the wood grain. For example, at the lower right of the specimen, there is a lower lateral tunnel (Fig. 8, lt), measuring $4.2 \mathrm{~cm}$ long and $\sim 0.35 \mathrm{~cm}$ wide (excluding a pronounced crack), which branches into three distinct larval tunnels (Fig. 7), each separated by a thin wood barrier. Above these tunnels is an initial tunnel that is $3.8 \mathrm{~cm}$ long and $0.15-0.18 \mathrm{~cm}$ wide and branches into five unequally spaced, largely unbranched tunnels (Fig. $8)$. These tunnels emerge from the lateral tunnel at approximately perpendicular $\left(90^{\circ}\right)$ to highly inclined $\left(60^{\circ}\right.$ to $\left.75^{\circ}\right)$ angles and curve away from the central gallery, forming a bend (Fig. 6) and becoming oriented parallel to the wood grain. The major lateral tunnels to the left, one of which is immediately adjacent the feeding tunnel, are less well preserved (Figs. 4, 8). This tunnel is $1.9 \mathrm{~cm}$ long, $0.18 \mathrm{~cm}$ wide, and consists of two branches. There is a short longitudinal tunnel $0.42 \mathrm{~cm}$ in diameter above the last mentioned tunnel that gives rise to five branches that originate from a secondary gallery. Four of these subsequently coalesce into another secondary gallery, after which they again become separate as three larval tunnels. The terminus of one tunnel of this set ends in an ovoidal expansion 0.7 by $0.4 \mathrm{~cm}$ in dimension and with a distinctive central whitened area 0.27 by $0.16 \mathrm{~cm}$ in dimension (Fig. 5), perhaps representing an inner coating resulting from frass.

From the upper margin of the enlarged central gallery, six branching tunnels perpendicularly emerge, but three are eventually deflected to the right, eventually becoming parallel to the wood grain (Fig. 8). Proximally, these branching tunnels range from 0.16 to $0.20 \mathrm{~cm}$ in diameter and are perpendicular or highly inclined to the wood grain, eventually becoming oriented parallel to the wood grain, and terminating as tunnels ranging from 0.28 to $0.32 \mathrm{~cm}$ in diameter. Three of these branching tunnels end as noticeable ellipsoidal expansions. One distinctive terminal expansion at the upper left is 0.6 by $0.3 \mathrm{~cm}$ in size.

Locality - The site from which the specimen was obtained is Napartulik, near the Geodetic Hills, eastern Axel Heiberg Island, Nunavut Territory, Canada, $79^{\circ} 55^{\prime} 02.0^{\prime \prime} \mathrm{N}, 88^{\circ} 58^{\prime} 20.4^{\prime \prime}$ $\mathrm{W}$. The specimen was found in a sandy facies near the top of the upper coal member.

Stratigraphic position-The stratigraphic occurrence of the specimen is from the Buchanan Lake Formation of the Eureka 
Sound Group; it was retrieved from the upper lignitic, coalbearing member. It is of middle Eocene age (Ricketts and McIntyre, 1986), corresponding to the Uintan North American land mammal age (41.3-47.5 Ma) and the Lutetian Stage (Gradstein and Ogg, 1996).

Plant host - The engraving was found on Larix altoborealis (LePage and Basinger, 1991b). This specimen is a short-bracted species with closest affinities to extant $L$. decidua Miller (European larch). It also exhibits some anatomical similarities to the long-bracted, extant species L. occidentalis Nuttall (western larch) of the Pacific Northwest and L. kaempferi (Lambert) Sargent (Japanese larch) of eastern Asia. The phytogeography of this species is discussed in LePage and Basinger (1991a, 1995a).

Interpretation, comparisons, and affinities-The engraving documented in Figs. 2-8 contains several structural details, such as the juxtaposition of the central gallery and a highly patterned tunnel network, which are unambiguous behavioral apomorphies of the Scolytidae and cannot be confused with any other known wood-penetrating insect taxon. This system of engravings, characterized by tunnels that are several millimeters in diameter, occur dominantly within the upper cambium, although there is evidence for consumption of the lower bark surface. This is a habitat that is overwhelmingly confined to the Scolytidae.

We interpret this gallery and tunnel system as follows. The feeding tunnel (Fig. 8, ft) was constructed by a parent beetle after oviposition and was used as an exit path after abandonment of the gallery. Only part of this tunnel is preserved; the remainder presumably resided in the bark of this decorticated specimen. The central gallery is the enlarged region of the egg tunnel (Fig. 8, cg). This central gallery resembles Balachowsky's (1949) "galerie longitudinale simple" and Choo's (1983) "horizontal flat gallery" configurations and may represent a nuptial gallery that was modified into an egg gallery reminiscent of modern angiosperm-feeding species of Cryphalus Erichson (Balachowsky, 1949, fig. 23) and Liparthrum Wollaston (Blackman, 1922). The surrounding tunnels indicate that the central gallery is an enlarged egg-laying region, particularly as several regularly spaced larval tunnels emerge from the upper margin of this chamber (Trägårdh, 1930; Stark, 1982). These tunnels extend from the central gallery on one side only, of which there are 21 individual tunnels recognizable at midlevel that terminate into 19 separate tunnels. Some of these tunnels initially are common larval tunnels that subsequently bifurcate into individual larval tunnels (Fig. 8, lt). These distinctive larval tunnels originate from the central gallery sidewall at highly-inclined to perpendicular angles (Fig. 8, lt). In at least two regions, there are secondary galleries (Fig. 8, sg) caused by the merging of separate larval tunnels into a larger chamber during larval development. They are characterized by the temporary joint occupation of a gallery by multiple larvae and are followed by the reestablishment of separate larval tunnels. Some larval tunnels terminate in pupal cells (Fig. 8, pc), characteristically elongate and ellipsoidal expansions that, in four complete examples, are enlarged to approximately twice that of larval tunnel width. Other more subtle terminal expansions probably do not represent pupal cells, but rather are associated with developmental size increases of feeding larvae that were suddenly aborted.

Within the Scolytidae, six lines of evidence represent be- havioral apomorphies and indicate that this fossil engraving is assignable to a monogynous species and to Dendroctonus in particular. First, there is a single gallery, which originated from a feeding tunnel that is partly preserved. This gallery is typical of the short-and-broad rather than the long-and-narrow configuration of Dendroctonus frontalis (Hopkins, 1909a, fig. 55) and D. brevicomis (Stark, 1982, fig. 2.1b). Such a shape represents an important behavioral apomorphy, in which the gallery formed is short and broad rather than long and narrow, but this behavior also is reminiscent of Cryphalus and Liparthrum, which construct egg-niches on the peripheral margin of an enlarged nuptial chamber (Blackman, 1922; Balachowsky, 1949).

Second, the occurrence of larval tunnels that emerge asymmetrically on one side of the central gallery is unusual for bark beetles (Figs. 3, 4, 8), and resembles closely the engravings produced by species such as the extant D. rufipennis (Kirby) on Picea (Hopkins, 1901, pl. 5; Wood, 1982, fig. 77c), and less so to those produced by D. pseudotsugae on Pseudotsuga Carrière (Hopkins, 1909b, fig. 66; Chamberlin, 1958, figs. 12, 39). Interestingly, the engravings of modern D. simplex on Larix laricina (Du Roi) K. Koch are quite different (Hopkins, 1909a, fig. 73), with larval tunnels emerging from both sides of the central gallery. An alternative, nonparsimonious explanation is that this asymmetry is explained as deliberate avoidance of the lower gallery margin during oviposition while the female parent was in the central gallery. Such avoidance possibly would be attributable to the presence of inclement levels of humidity or temperature or unusual surface conditions within the chamber. However, there is no direct evidence for this.

Third, there is no indication of a nuptial chamber or "turning zone" from which multiple branches, particularly elongate egg galleries, widen, as is seen in Ips DeGeer (Kabe, 1954, pl. 19), Phloeosinus Chapuis (Trägårdh, 1930), Leperesinus Reitter (Balachowsky, 1949, fig. 21), and numerous other genera. Rather, there is a broad central gallery, the product of behavior consistent with species of Tomicini, particularly Dendroctonus, examples of which include D. rufipennis (Hopkins, 1909a, figs. 79 and 81; Massey and Wygant, 1954, fig. 10) and D. pseudotsugae (Bedard, 1950, fig. 3).

The fourth and fifth features that indicate larval coexistence within tunnels or galleries are important for taxonomic assignment of this specimen. Fourth, there is the presence of secondary galleries where larvae occur in congress (Fig. 8, sg). Although uncommon in bark beetles, secondary galleries have been documented in various species of Dendroctonus, particularly D. rufipennis (Fig. 9; Werner, Baker, and Rush, 1977, fig. 4), but also D. micans (Hopkins, 1909a, fig. 88b) and $D$. valens (Hopkins, 1909a, fig. 91c). This feature also occurs in some primitive scolytid genera occurring on tropical angiosperms. The overwhelming occurrence of agonistic response and cannibalism among scolytid larvae probably does not allow for the widespread presence of secondary galleries.

The fifth feature, also indicating larval coexistence, is the presence of larval tunnels that are initially inhabited by multiple larvae, but subsequently dichotomize some distance from the central gallery and become separate (Fig. 8, right lt). In almost all scolytid genera, larval tunnels initially are separate and remain subparallel to each other for the entire endophytic phase of the life cycle, from eclosion to pupation. This phenomenon also applies to the crossing of larval tunnels, which appears to be present in the upper-left region of Fig. 8. This 


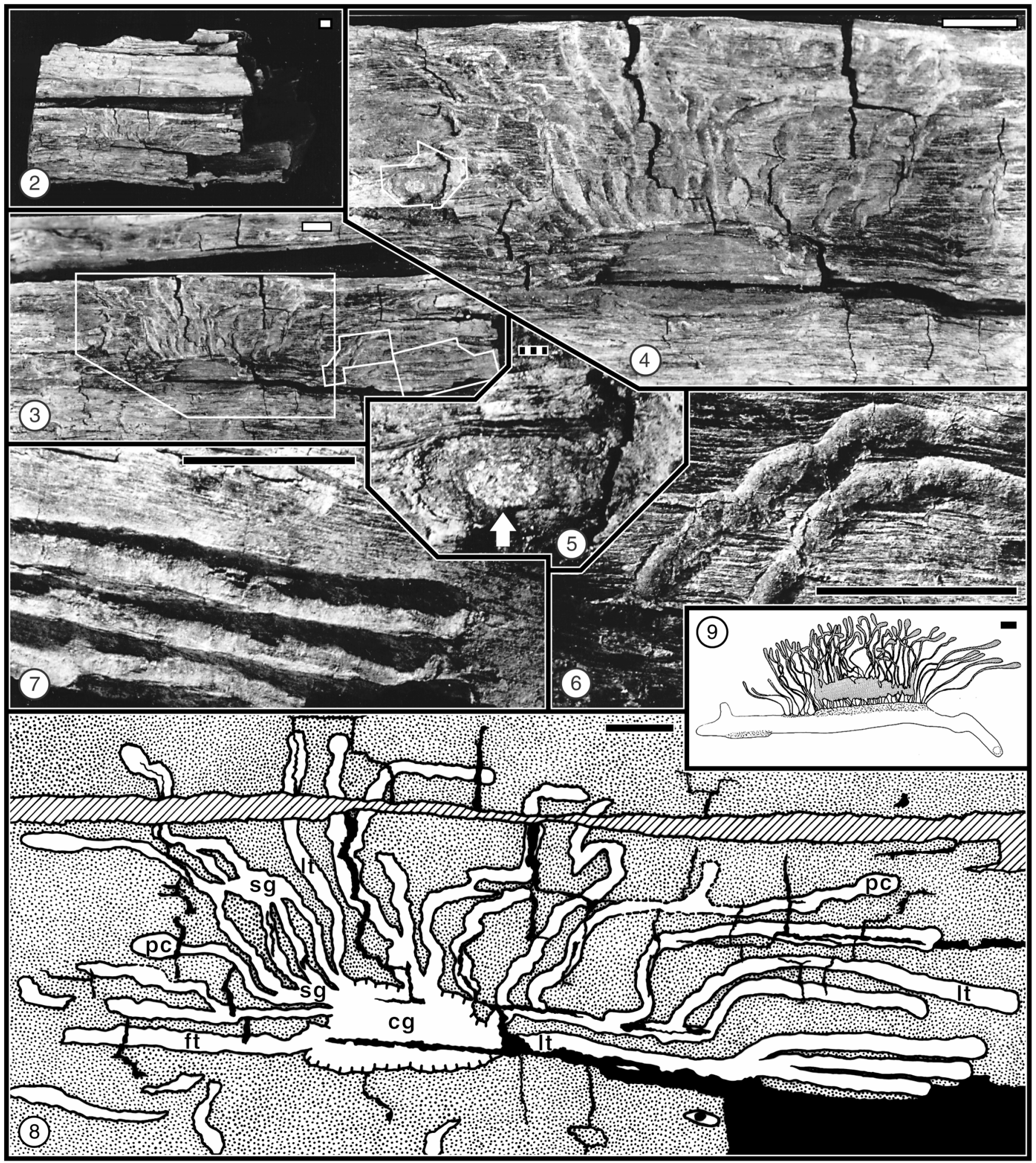

Figs. 2-9. Scolytid engraving of cambial zone of middle Eocene Larix altoborealis, showing detail of gallery and tunnel system and a similar modern engraving by Dendroctonus rufipennis. Solid scale bar $=1 \mathrm{~cm}$; in Fig. 5 the striped scale bar $=0.1 \mathrm{~cm}$. 2. Mummified Larix altoborealis log with scolytid bark engraving visible in the central region, immediately below a pronounced longitudinal crack. Left margin of log is hand sawn; right margin is irregularly fractured. 3. Enlargement of bark engraving in Fig. 2, displaying the entire preserved network of tunnels and galleries. 4. Enlargement of central region of bark engraving outlined in Fig. 3, showing larval tunnels emerging from egg-laying tunnels that, in turn, originate from the ovoidal nuptial gallery. 5. Enlargement of pupal chamber in Fig. 4 showing an ovoidal cavity with a central, whitened area representing a portion of the frass plug. 6. Transition of larval tunnel from an earlier phase of engraving inclined obliquely to the wood grain, to a subsequent phase of engraving parallel to the wood grain. See Fig. 3 for position. 7 . Detail of larval tunnels and their termini outlined in Fig. 3. Note apposition of three larval tunnels separated by thin partitions of wood. 8. Cameral lucida drawing of Fig. 3 with interpretation of structures. The angular pattern of slashes at top indicates that the pronounced longitudinal crack in Figs. 2 and 3 has 
feature occurs rarely in extant Tomicini and represents a primitive condition (S. Wood, Brigham Young University, personal communication).

The sixth and final behavioral apomorphy is that the spacing and extent of egg-laying along the margin of the central gallery. This is an important feature, but has multiple explanations. The fossil material exhibits a distinct irregularity in the interval by which eggs were oviposited in sidewall niches of the central gallery. Most scolytid species place eggs at a regular, approximately equal interval. In most tomicines, including Dendroctonus, this interval is highly variable, with placement of one to several eggs in each niche, as indicated by the presence of one to five distal branches for each proximal larval tunnel. Apparently, most larvae hatched from a single niche with multiple eggs, initially occupying a common tunnel before diverging into separate tunnels, as in D. pseudotsugae (Anderson, 1960, figs. 10, 13; Johnson and Lyon, 1991, pl. 26, fig. g). The number of eggs per centimeter of the central gallery length is $\sim 20$, which is almost the same as modern Dendroctonus (Wood, 1982). A less likely alternative is that this irregularity could be interpreted as part of the disruptive microecological conditions within the gallery system that may have been responsible for the absence of oviposition on the lower margin of the central gallery.

The size and structure of the central gallery, larval tunnels, and pupal cells largely circumscribe Dendroctonus and are typical of the tribe Tomicini in general (Bedard, 1950, fig. 3; Werner, Baker, and Rush, 1977). The former is the most extensively studied and documented extant genus of the tribe. Notably, in one pupal cell, the presence of whitish material adhering to the cell wall (Fig. 5) is similar to material deposited by parasitoids in modern bark-beetle taxa (Berisford, Kulman, and Pienkowski, 1970). The position of pupal cells as enlarged elliptical-elongate termini parallel to the wood grain occurs in modern species Dendroctonus and other members of the tribe Tomicini (Chamberlin, 1939; Balachowsky, 1949), but also in numerous other genera.

This scolytid engraving is attributed to an unidentified species of Dendroctonus, whose closest relatives are the Pinaceaefeeding Eurasian Tomicus Latreille (8 species) and Hylurgus Latreille (2 species) and the North American Pseudohylesinus Swaine (11 species) (Peyerimhoff, 1919; Chamberlin, 1958, figs. 58-60; Bright, 1969, figs. 29-33). It is based on the six behavioral apomorphies itemized above: (1) the presence of a single egg gallery, (2) asymmetrical origin of larval tunnels, (3) lack of a "turning zone" in the central gallery, (4) secondary chambers, (5) branching larval tunnels, and (6) irregular spacing of egg niches along the gallery margin. Other less exacting criteria are consistent with such an assignment. It is notable in this context that extant tamarack, Larix laricina, with a transcontinental distribution extending from north-central Alaska to the New England Seaboard, is extensively and monophagously attacked by $D$. simplex (Langdor and Raske, 1987a, b), although the gallery structure of this extant species is significantly different from its fossil congeneric host. In fact, the gallery of $D$. simplex is more similar to a few of its distantly related Pinus-feeding species (Hopkins, 1909b, figs. 45, 63; Furniss, 1976, fig. 9; Rose and Lindquist, 1992, p. 60; but see Wilson, 1977, fig. 68g), than to its own sister-species, whose host is Pseudotsuga. Additionally the fossil material can be excluded from the more diverse clade that exclusively parasitizes Pinus (Wood, 1982; Kelley and Farrell, 1998), due to its lack of gallery systems characterized by very elongate egg chambers, thin and short larval tunnels placed at approximately regular and equal intervals on both sides of the egg chamber, and proportionately large pupal chambers (Hopkins, 1909b, fig. 45 for D. ponderosae; Wood, 1982, fig. 64 for $D$. adjunctus; Beal and Massey, 1945, pl. 14 for D. frontalis). Within Dendroctonus, the fossil scolytid gallery is closest to that of D. rufipennis, whose hosts are all species of Picea, and to D. pseudotsugae, whose hosts are Pseudotsuga menziesii (Mirbel) Franco (Douglas fir), P. macrocarpa (Vasey) Mayr (bigcone fir), and perhaps Tsuga heterophylla (Rafinesque) Sargent (western hemlock) and Larix occidentalis. Although structural attributes of the Eocene bark engraving circumscribe a Dendroctonus relationship, definitive generic identification needs to be bolstered by examination of variability of additional complete gallery and tunnel systems on specimens of Larix altoborealis. In summary, this Eocene fossil can be placed in an older, Pinaceae-feeding lineage of Dendroctonus; apparently it became extinct as subsequent Dendroctonus species later colonized Holarctic pinaceous conifers.

\section{DISCUSSION}

Described examples of scolytid bark engravings are rare in the fossil record. The discovery of a scolytid engraving attributed to a well-known and economically important genus that is linked to an Eocene member of a distinctive conifer lineage offers an unique opportunity to evaluate the history of a wellstudied system of extant plant-insect associations. In the following discussion, we will evaluate the history of Dendroctonus and other scolytid wood-borers of conifers. In particular, we will incorporate additional data that address the absence or persistence of geochronologically long-term plant-insect associations in this lineage.

Fossil history of the Scolytidae and their gymnosperm hosts-Boring into or engraving of wood and other vascular plant tissues is an ancient life habit (Labandeira, 1998a, b). The earliest well-documented examples from the fossil record are detritivorous oribatid mite borings in a variety of plant hosts from a 17-million-year interval during the Late Carboniferous of North America (Cichan and Taylor, 1982; Labandeira, Phillips, and Norton, 1997). Oribatid mite borings into wood also are known from the Permian of Europe (Goth and Wilde, 1992) and Antarctica (Weaver, McLoughlin, and Drinnan, 1997). Borings of considerably larger diameter occur in Permian glossopterid woods (Zavada and Mentis, 1992; Weaver, McLoughlin, and Drinnan, 1997) and are attributed to insects, possibly beetles (Labandeira, 1997, 1998a). The earliest solid evidence for beetle wood borings originates from the Late Triassic of Germany (Linck, 1949) and Arizona, USA (Walker, 1938). Three distinctive types of borings and engravings were described by Walker (1938), the culprits of which could have been buprestid or cerambycid beetles (Wood, cited

\section{$\leftarrow$}

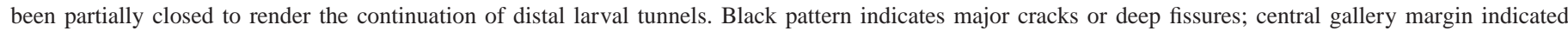
by hatchures. 9. Modern gallery of Dendroctonus rufipennis (Kirby) on Picea (spruce). Reproduced from Wood (1982). 
in Boucot, 1990). Of these, the ichnogenus Paleoipidus Walker, occurring in wood of Araucarioxylon Kraus in Schimper, could have been constructed by a member of the Platypodidae (Wood, cited in Boucot, 1990), a family of wood-boring beetles closely related to the Scolytidae (Wood, 1973, 1986). Several Jurassic occurrences of beetle wood borings have been attributed to the Cupedidae, Cerambycidae, and Buprestidae (Zhou and Zhang, 1989; Tidwell and Ash, 1990; Genise and Hazeldine, 1995). However, none illustrate the highly stereotyped gallery and tunnel patterns typical of even the most primitive Scolytidae. Although Crowson (1981) supported the above observations by stating that the Scolytidae did not differentiate until the Cretaceous (also see Ponomarenko, 1995), others indicate that an earlier Mesozoic origin on conifers is more likely (Sturgeon and Mitton, 1982; Wood, 1982). This is likely, although earlier Mesozoic woods may lack sufficient or well-enough developed structural features to allow assignment to the Pinaceae.

The first well-documented scolytid engravings are known from Lower Cretaceous coniferous wood and cones. The best example was initially described without illustration (Blair, 1943) from a decorticated conifer log with radiating cambial tunnels originating from undefined central chambers. Blair (1943) compared these cambial engravings to the extant scolytid beetle Hylastes palliatus Gyllenhall, although Wood (1986) indicated that they resemble the galleries of certain Ctenophorini. Subsequently, this and additional material were described and refigured by Jarzembowski (1990), who established its age as late Berriasian to mid-Valanginian and formally assigned it to Paleoscolytus Walker (1938) as P. sussexensis Jarzembowski. Other illustrations of this material are provided in Jarzembowski (1984), Stephenson (1991), and Scott, Stephenson, and Chaloner (1992). This material was reassigned by Stephenson (1991) to a curculionid weevil similar to extant Pinaceae-feeding Pissodes, which constructs a radial system of larval tunnels originating from a single egg chamber (Hopkins, 1911, pl. 15c). Nevertheless, this engraving bears several behavioral features characteristic of the Scolytidae, of which undescribed body fossils have been recorded from slightly younger (Hauterivian) Lebanese amber (Jarzembowski, 1990). A second, somewhat younger Lower Cretaceous (Aptian) scolytid gallery system was described in the axis of the cone Pityostrobus milleri Falder et al. (1999). The damage of this cone resembles that of extant Conophthorus Hopkins of the tribe Corthylini, which attack Pinus strobus L. (Bright, 1976, fig. 189; Furniss and Carolin, 1977, fig. 225). An additional scolytid engraving, on Late Cretaceous coniferous bark, was discussed and illustrated by Brongniart (1877) and has been subsequently corroborated by Wood (1982; cited in Boucot, 1990). More recent mid-Cenozoic scolytid engravings also have been found in resin-embedded bark in Baltic amber (fig. 112 in Krzeminska, et al., 1992). Other Cenozoic scolytid engravings occasionally occur in compression deposits such as Scolytolarvariumichnus radiatus Guo (1991), described from the middle Miocene Shanwang Formation from Shandong, China: these are similar to engravings on Sphaerotypes on Shorea Roxburgh ex C.F. Gaertner (Browne, 1961) or on Carpinus L. (Kabe, 1954). Also, a scolytid engraving was assigned to Pithyogenes chalcographus (L.), from the Miocene of Lower Silesia, Poland (Karpinski, 1962; Radwanski, 1977). Geochronologically more recent scolytid galleries were noted on Larix groenlandii Bennike in Peary Land of northern Greenland, from the late Pliocene Kap København
Formation of Peary Land (2.0-2.5 Ma), northernmost Greenland, but no co-occurring Dendroctonus were found (Böcher, 1989; Bennike and Böcher, 1990). Other than our middle Eocene specimen, the only described Dendroctonus brood gallery in the fossil record of which we are aware is unassigned scolytid damage on Picea glauca (Moench) Voss from the late Pleistocene (125000 yr BP) of the Eva Interglaciation Forest Bed, east-central Alaska, USA (Péwé et al., 1997). Although not identified in the original report, the species of this engraving undoubtedly is $D$. punctatus.

Whereas there are known scolytid body fossils from late Mesozoic strata, it is body-fossil taxa that dominate the midCenozoic fossil record. The two types of scolytid-bearing deposits are lithified lacustrine sediments and amber, the former presenting a negative and the latter a positive taphonomic bias for the preservation of wood-inhabiting beetles (Poinar, 1992; Smith, 2000). The earliest well-known assemblage of body fossils is from the early middle Eocene deposits of the Green River Formation of Wyoming, described by Scudder (1876, 1878, 1893) and Hopkins (1900). Younger material containing a greater diversity of taxa also have been described for the Florissant Formation, from the latest Eocene of Florissant, Colorado, USA (Scudder, 1893; Hopkins, 1900; Wickham, 1913, 1916). However, the scolytid material of both of these compression assemblages needs to be redescribed, as many of the taxonomic designations have been superseded by subsequent neoentomological work.

In contrast to compression material, the best preserved fossil scolytid material typically occurs in amber deposits. The most speciose amber fauna is from the Baltic region of late Eocene age (Hagedorn, 1906, 1907b; Schedl, 1947; Bachofen-Echt, 1949; Larsson, 1978; Spahr, 1981). As reevaluated by Wood and Bright (1992), this deposit consists of $\sim 23$ species of bark beetles in seven mostly primitive genera, two of which are fossil. Of these, the Pinaceae-feeding Hylastes and Hylurgops represent the sister group (Hylastini) to Dendroctonus (Sequeira, Normark, and Farrell, 2000) and provide a minimal age for that genus as late Eocene, or $\sim 38 \mathrm{Ma}$ (Gradstein and Ogg, 1996). Early Miocene Dominican amber has produced 20 scolytid species (Bright and Stock, 1982; Grimaldi, 1996), which are allocated to 14 genera, of which 6 are extinct (Bright and Poinar, 1994). The two most abundant amber deposits-Baltic and Dominican amber-lack Tomicini taxa, in spite of preserving 43 species and 21 mutually exclusive genera. This is explained possibly by the lack of conifer hosts in these biotas. One notable exception of the late Eocene pinaceous resin producer, "Pinus" succinifera Conwentz from the Baltic region, which evidently is related to extant Pseudolarix of the Abietoideae (Anderson and LePage, 1995). Dendroctonus body fossils are uncommon in glacially associated latest Pleistocene to early Holocene deposits, but have been found in southern Ontario, Canada; Minnesota, USA; and the Front Range of Colorado, USA, represented by D. rufipennis, $D$. simplex, and unassigned species, often with co-occurring needles or wood of Picea and Larix (Ashworth, 1977; Ashworth et al., 1981; Elias, 1985).

The colonization of Pinaceae by Dendroctonus and its immediate ancestors - Extant conifers consist of seven to nine families representing $\sim 600$ species, of which the Pinaceae are the most speciose, amounting to $\sim 215$ species or $\sim 35 \%$ of the total (Farjon, 1990; Mabberley, 1993). Within the Pinaceae, four subfamilies comprised of 11 genera are recognized 
(Frankis, 1989; Farjon, 1990). The subfamilies are Pinoideae (Pinus), Piceoideae Frankis (Picea), Laricoideae Melchior et Werdermann (Larix, Pseudotsuga, and Cathaya Chun et Kuang), and Abietoideae Pilger (Abies Miller, Cedrus Trew, Keteleeria, Nothotsuga, Hu ex Page, Pseudolarix, and Tsuga). Molecular studies based on chloroplast DNA generally support this classification (e.g., Chaw et al., 1997; Stefanovic et al., 1998). These subfamilies have been analyzed phylogentically by a variety of methodologies beginning in the late 1980s, and there is general agreement that the major Pinaceae subclades have an Abietoideae + [Pinoideae + (Piceoideae + Laricoideae)] topology and, in particular, there is a close sister-group relationship between the Piceoideae + Laricoideae (Hart, 1987; Price, Olsen-Stojkovich, and Lowenstein, 1987; Frankis, 1989; Farjon, 1990; Chase et al., 1993; Tsumura et al., 1995; Chaw et al., 1997; Xiao-Quan et al. 1997). Larches (Larix), a focus of this study, are ecologically distinctive within the Pinaceae by their deciduousness (Tilton, 1977; LePage and Basinger, 1991b), a feature that occurs rarely and sporadically throughout the Pinaceae, as well as by their occurrence in the most extreme of environments, above northern and elevational limits for typical conifer growth (Gower and Richards, 1990).

The genus Dendroctonus is a member of the Tribe Tomicini within the subfamily Hylesinae; its closest relatives are the Pinaceae-feeding genera Tomicus, Hylurgus, and Pseudohylesinus (Wood, 1982). Dendroctonus is a widespread, cold-temperate to subtropical clade of 19 species, of which 17 occur in North America and 2 in Eurasia (Wood, 1982; Bentz and Stock, 1986; Zúñiga et al., 1999). Of the Eurasian taxa, the Chinese species D. armandi Tsai and Li (1959) occurs on Pinus armandii Franchet (Kurentzov and Kononov, 1966; Yin, Huang, and Li, 1984) and is basal to all other species (Wood, 1982; Kelley and Farrell, 1998). The other, D. micans, occurs on Picea and Pinus (Yanovskij, 1999) but is a member of a widespread North American group that represents a past intercontinental dispersal event. Three major lineages of Dendroctonus exist: a basal Pinus-inhabiting clade consisting of the single species D. armandi (Kurentzov and Kononov, 1966), and two derived sister-clades. One of these consists of 12 species on Pinus and the other is a clade of six species. Of the latter, one subclade contains four species, three that have colonized Picea (Massey and Wygant, 1954; Schmid and Frye, 1977), and the other subclade consists of two species, one on Larix and one on Pseudotsuga (Bedard, 1950; Lanier, 1981; Werner, 1986; Kelley and Farrell, 1998). These phloem-feeding taxa are monophagous (species specific), or oligophagous at either the first level, in which there is colonization of multiple host-species in the same genus, or less commonly at the second level, characterized by establishment among multiple host-species within closely related genera (Stark, 1982; Sturgeon and Mitton, 1982). Some instances of second-level oligophagy or even rare polyphagy may reflect mere presence of larvae or adults on an atypical host rather than true completion of a life cycle. For example, one instance of second-level oligophagy has been ruled out in D. micans, which is said to colonize species of Picea and Pinus, but has been found on Pseudotsuga, Abies, and Larix (Wood, 1982). However, the beetle is now known to lack the ability for completing larval development in the three latter genera (Wainhouse and BeechGarwood, 1994). Because of their high level of host specificity and well-described life habits, Dendroctonus is a near-ideal system for detecting coevolutionary associations among a tractable number of distinctive hosts. Their highly distinctive pat- terns of subcortical damage allows for assignments usually to the generic level, particularly since a rich literature has been devoted to gallery and tunnel recognition among all target trees of the Pinoideae, particularly on Douglas fir by D. pseudotsugae and ponderosa pine by $D$. ponderosae (Keen, 1952; Furniss and Carolin, 1977; Johnson and Lyon, 1991). Moreover, owing to their profound economic impact on valuable timber trees, the life history of no other bark beetle genus has been as intensively examined as Dendroctonus, with the possible exception of Ips (Bright, 1976).

Figures 10 and 11 illustrate the phylogeny of the four subfamilies of Pinaceae hosts and contrast two hypotheses explaining their colonization by Dendroctonus lineages. The hypothesis of plant-host relationships is based on "consensus" data among the four subfamilies constituting the Pinaceae, discussed above, while their bark beetle colonizers are represented by the results of a study by Kelley and Farrell (1998) based on mitochondrial DNA sequence data. Included as a sister-lineage to Dendroctonus is the closely related Hylastini (node 1), demonstrated by Sequeira, Normark, and Farrell (2000). Based on the preferred hypothesis presented in Fig. 10, once Dendroctonus originated, it colonized Pinoideae (Pinus) first, currently represented by the basal clade (not shown) of Dendroctonus armandi on Pinus armandii from China (collapsed onto node 2). This was followed by a subsequent cladogenetic event in which the ancestor of a diverse clade of 12 extant species again colonized Pinus (node 2), the ancestral host. Then its sister-group diverged into two clades, one now consisting of three extant species colonizing Picea of the Piceoideae (node 3 ) and the other presently containing two extant species colonizing the Laricoideae, namely, Pseudotsuga (node 4) and Larix (node 5). Given this colonization sequence, and including the Eocene fossil occurrence, there is congruence between the inferred order of appearance of host-plant genera and their Dendroctonus bark beetle associates. The sequence is Pinoideae, and subsequently Piceoideae + Laricoideae. Based on the preexisting occurrence of Cretaceous Pinoideae, Piceoideae, and Laricoideae, an earlier existence can be posited for the Tomicini in general and Dendroctonus in particular as a relatively early lineage of the Scolytidae. Including the paraphyletically interspersed Hylastini, Polygraphini, and the secondarily angiosperm-feeding Hylesinini (Sequeira, Normark, and Farrell, 2000; see also Kuschel, Leschen, and Zimmerman, 2000). These lineages feed almost entirely on Pinaceae and Araucariaceae, providing circumstantial evidence for late Mesozoic colonization events. The absence of relevant body fossils in appropriate deposits could be attributable to the lack of searching or taphonomic bias, although undescribed scolytids have been reported from Early Cretaceous Lebanese amber (Jarzembowski, 1990). Additionally, there is the possibility of the lack of recognition of appropriate scolytid engravings in conifer woods from warm-to cool-temperate floras of the North American Cretaceous and Paleocene. The most parsimonious interpretation is the geochronological origination of Dendroctonus relatively early in the phylogenetic history of the Pinaceae and its four constituent clades. This is consistent with the parallel cladogenesis model of Brooks and Mitter (1984).

An alternative interpretation of the occurrence of a middle Eocene Dendroctonus engraving on Larix (Fig. 11) is to posit a delayed colonization of Pinaceae until the mid-Cenozoic (Wood, 1986). This view holds that Dendroctonus is not phylogenetically basal within the Scolytidae and represents a de- 

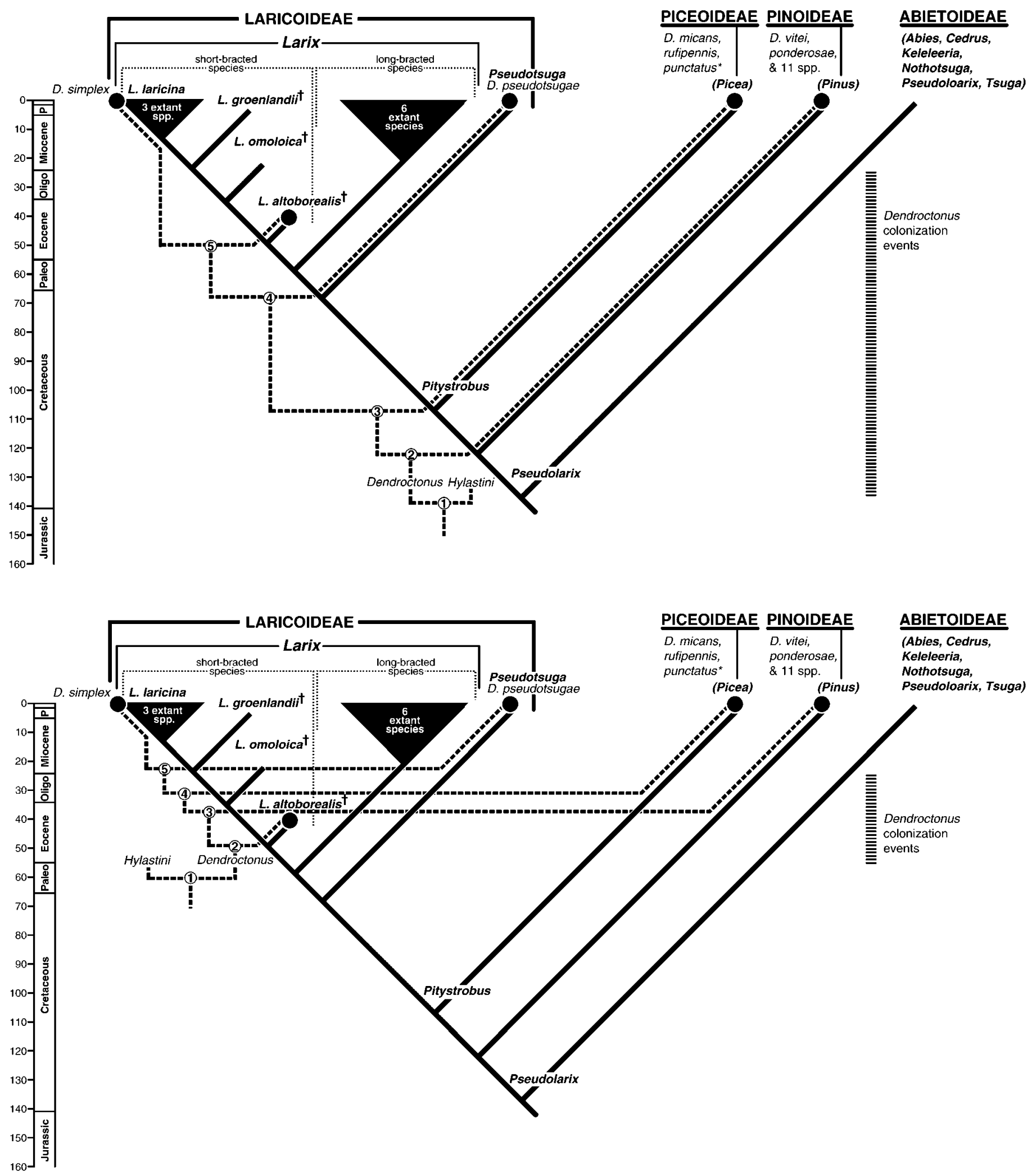

Figs. 10-11. Coupled phylograms showing two hypotheses for the evolutionary colonization by ancestral lineages of Dendroctonus bark beetles (dashed lines, taxa with normal font) of their pinaceous hosts (solid lines, taxa with bold font) that belong to the subfamilies Pinoideae (Pinus), Piceoideae (Picea), and Laricoideae (Larix and Pseudotsuga). 10. The preferred hypothesis is based on a geochronologically older origin of Dendroctonus, supporting the Pinaceaefeeding sister-groups (Dendroctonus + Hylastini). Additional support is provided by more basal taxa to the Dendroctonus + Hylastini clade that feed on Pinaceae (Sequeira, Normark, and Farrell, 2000). 11. An alternate hypothesis is based on the geochronologically recent origin of Dendroctonus (Wood, 1986), indicating that conifer-feeding is a secondary acquisition. 
rived lineage that secondarily acquired pinaceous hosts (Wood, 1986), in contrast to the analysis of Sequeira, Normark, and Farrell (2000). Interestingly, the sequence of colonization of major pinaceous clades by Dendroctonus, as determined by the analyses of Kelley and Farrell (1998), is topologically congruent with their plant-host phylogeny deduced by a variety of molecular, anatomical, and fossil data. Accordingly, rather than positing parallel cladogenesis that is consistent with the phylogenetically basal congruent radiation of Dendroctonus and subclades of Pinaceae, the sequential evolution model of Jermy (1984) would best explain a delayed colonization. However, based on what is known of the phylogenetic relationships and history of the Pinaceae and Dendroctonus, it appears that mid-Cenozoic sequential evolution is highly unlikely.

An interesting pattern is present in the colonization history of Larix. Evidently only the currently less diverse, typically lowland-inhabiting, short-bracted larches were colonized by extant and middle Eocene species of Dendroctonus. There is the single exception of $D$. pseudotsugae that has been collected on the long-bracted Larix occidentalis (Wood, 1982), though complete life cycle viability on this host needs to be confirmed (also see Wainhouse and Beech-Garwood, 1994). All other occurrences of Dendroctonus are on short-bracted species, namely North American L. laricina and the Eurasian L. sibirica Ledebour (Wood, 1963, 1982; Bright, 1976; Yanovskij, 1999). Curiously, Rozhkov (1970) did not record Dendroctonus in a compendium of phytophagous insects on Siberian larch, $P$. sibirica. The colonization of Larix by the Tomicini occurred by middle Eocene time (Jagels, LePage, and Jiang, 2001); it was again colonized during the later Cenozoic by Dendroctonus simplex. Nevertheless, the major exception to the colonization of Larix is the conspicuous absence of Dendroctonus on the twice-as-speciose, long-bracted, mostly montane species. This is a pattern that begs an explanation. Perhaps an answer involves a distinctive spectrum of terpene and other resin volatiles that have been deterrents rather than attractants to potential Dendroctonus colonizers.

The persistence of plant-insect associations in macroevolutionary time-The occurrence of a middle Eocene tomiciine brood gallery on Larix is relevant for understanding the maintenance of host specificities among a tribe of bark beetles and their pinaceous hosts during the past 45 million years (Futuyma and Moreno, 1988). The assignment of this engraving to an earlier representative of Dendroctonus implies that the Pinaceae were colonized by the middle Eocene and later were recolonized by modern Dendroctonus species or were continuously colonized by this evolving lineage. These and other fossil and phylogenetic data indicate the early colonization of Pinaceae by Dendroctonus (Fig. 10) and the phylogenetically basal origin of the genus within the Scolytidae is consistent with parallel cladogenesis. In this context, the long-term avoidance of feeding on long-bracted species of $L a$ rix is significant, considering that the avoided species of Larix are more species diverse than the colonized species. Fortunately, there have been investigations into the nature of bark beetle isolation mechanisms in the Pinaceae, and a consensus indicates that various volatile compounds occurring in conifer oleoresin, principally terpenoids, act as attractants or deterrents to particular Dendroctonus species. This allows for the securing of certain host species and the avoidance of other species (Renwick and Vité, 1970; Werner et al., 1981), which may be the case for the long-bracted Larix species. At low concentrations, some terpenenoids are attractants to certain Dendroctonus species, whereas at elevated levels, these same compounds often act as deterrents (Renwick and Vité, 1970; Cook and Hain, 1988). In many instances, these volatile compounds chemically mimic or are the same as mass-aggregation pheromones produced by their host-specific bark beetles, thus serving as direct lures to host trees (Rudinsky, 1963; Renwick and Vité, 1969). The nature of the terpenoid chemical spectra, timing of response elicitation, concentration level, production of secondary beetle pheromones, and other life history aspects contribute to a complex interplay at many biological levels, moderating the types and levels of bark beetle infestation. For example, the production of appropriate secondary pheromones by females consuming suitable phloem of host trees will attract conspecific males for mating in galleries, resulting in subsequent gallery construction and oviposition (Rudinsky, 1963, 1968).

Monoterpenes are low-molecular-weight, volatile byproducts of terpenoid metabolism that occur in conifers (Sturgeon and Mitton, 1982) and undoubtedly were present in ancestral Mesozoic members of the Pinaceae. Typically such compounds deter insects, not only in conifers, but also in a wide array of angiosperms (Harborne, 1972). During geologic time, such initial insect deterrents also can be used by insect herbivores that evolve the ability to metabolically detoxify compounds such as terpenoids or even sequester them for defense against potential predators. A well-documented case is the association between Bursera N. J. Jacquin ex L. (Burseraceae) and its Blepharida Chevrolat (Chrysomelidae) herbivores, which is a prime macroevolutionary example of an insect clade tracking the chemical similarity rather than the phylog-

$\leftarrow$

The plant-host phylogeny is based on molecular sequence data and morphology (Frankis, 1989; Farjon, 1990; Chase et al., 1993; Tsumura et al., 1995; Xiao-

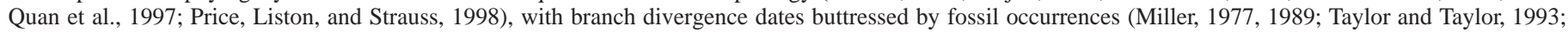

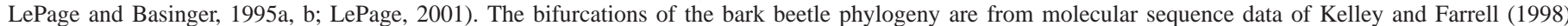

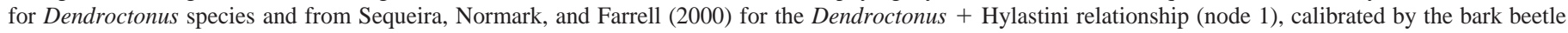

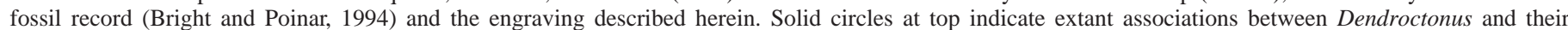

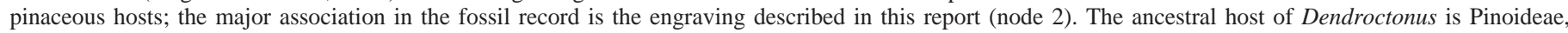

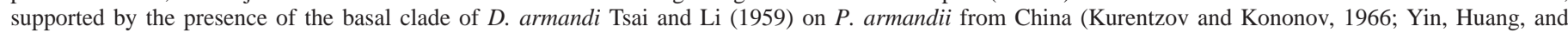

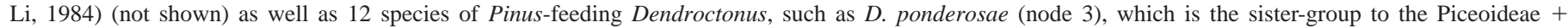

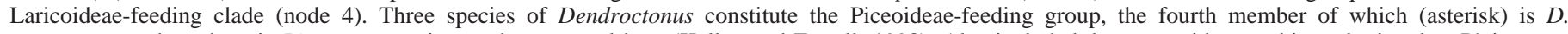

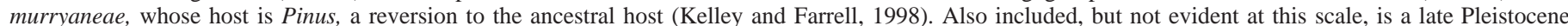

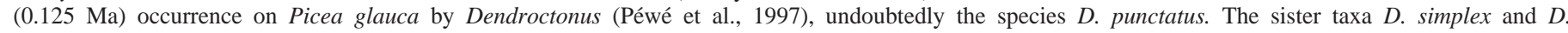

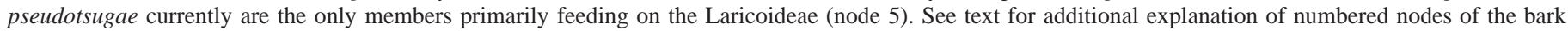
beetle phylogeny. Abbreviations: P, Pliocene; Oligo, Oligocene; Paleo, Paleocene; daggers indicate extinct taxa. 
eny of its hosts per se (Becerra, 1997; Becerra and Venable, 2000). This type of host specialization and tracking by insects also has been extensively demonstrated for Dendroctonous and its Pinoideae hosts (Lanier and Burkholder, 1974; Sturgeon and Mitton, 1982). Although the historical data are tentative, we suggest that the interplay of modern-aspect host conifer and bark beetle terpenoid compounds (Pinaceae and Dendroctonus) has been in existence during the past 45 million years at the minimum. This interplay also may be related to the conspicuous absence of colonization of one Laricoideae lineage, namely the long-bracted Larix clade. Future fossil evidence may extend the association with Dendroctonus and other Tomicini bark beetles to older Piceoideae, Pinoideae, and perhaps Abietoideae lineages, based on diagnostic and stereotypical damage patterns, similar in extension to the Late Cretaceous colonization of Zingiberales by hispine beetles (Wilf et al., 2000) and the earlier Cretaceous occurrence on Platanaceae of modern taxa of nepticulid leaf-miners (Labandeira et al., 1994).

\section{LITERATURE CITED}

Anderson, K., And B. A. LePage. 1995. Analysis of fossil resins from Axel Heiberg Island, Canadian Arctic. American Chemical Society Symposium Series 617: 170-192.

ANDERSON, R. F. 1960. Forest and shade tree entomology. John Wiley, New York, New York, USA.

Ashworth, A. 1977. A late Wisconsinin coleopterous assemblage from southern Ontario, and its environmental significance. Canadian Journal of Earth Sciences 14: 1625-1634.

Ashworth, A., D. P. Schwert, W. A. Watts, ANd H. E. Wright, JR. 1981. Plant and insect fossils at Norwood in south-central Minnesota: a record of late-glacial succession. Quaternary Research 16: 66-79.

BACHOFEn-ECht, A. 1949. Der Bernstein und seine Einchlüsse. SpringerVerlag, Vienna, Austria.

Balachowsky, A. S. 1949. Coleoptèrés. Scolytides. Faune de France 50: 1-320. Paul Lechevalier, Paris, France.

BAsinger, J. F. 1991. The fossil forests of the Buchanan Lake Formation (early Tertiary), Axel Heiberg Island, Canadian High Arctic: preliminary floristics and paleoclimate. Bulletin of the Geological Survey of Canada 403: 39-65.

Basinger, J. F., E. E. McIver, And B. A. LePage. 1988. The fossil forests of Axel Heiberg Island. Musk-Ox 36: 50-55.

Beal, J. A., AND C. L. MAssey. 1945. Bark beetles and ambrosia beetles (Coleoptera: Scolytoidea) with special reference to species occurring in North Carolina. Duke University School of Forestry 10.

BECERRA, J. X. 1997. Insects on plants: macroevolutionary chemical trends in host use. Science 276: 253-256.

Becerra, J. X., And D. L. Venable. 2000. Macroevolution of insect-plant associations: the relevance of host biogeography to host affiliation. Proceedings of the National Academy of Sciences 96: 12 626-12631.

Bedard, W. D. 1950. The Douglas-fir beetle. United States Department of Agriculture Circular 817: 1-10.

BENNIKE, O., AND J. BÖCHER. 1990. Forest-tundra neighbouring the North Pole: plant and insect remains from the Plio-Pleistocene Kap København Formation, North Greenland. Arctic 43: 331-338.

Bentz, R. J., AND M. W. STOCK. 1986. Phenetic and phylogenetic relationships among ten species of Dendroctonus bark beetles (Coleoptera: Scolytidae). Annals of the Entomological Society of America 79: 527-534.

Berisford, C. W., H. M. Kulman, and R. L. Pienkowski. 1970. Notes on the biologies of hymenopterous parasites of Ips spp. bark beetles in Virginia. Canadian Entomologist 102: 484-490.

Blackman, M. W. 1922. Mississippi bark beetles. Mississippi Agricultural Experiment Station Technical Bulletin 11.

BLAIR, K. G. 1943. Scolytidae (Col.) from the Wealden Formation (Middle or Lower Cretaceous). Entomologists Monthly Magazine 79: 59.

BöCHER, J. 1989. Boreal insects in northernmost Greenland: palaeoentomological evidence from the Kap København Formation (Plio-Pleistocene), Peary Land. Fauna Norvetica 36B: 37043.
Boucot, A. J. 1990. Evolutionary paleobiology of behavior and coevolution. Elsevier, Amsterdam, The Netherlands.

BRIGHT, D. E. 1969. Biology and taxonomy of bark-beetle species in the genus Pseudohylesinus Swaine (Coleoptera: Scolytidae). University of California Publications in Entomology 54: 1-46.

BRIGHT, D. E. 1976. The bark beetles of Canada and Alaska. The insects and arachnids of Canada, part 2. Biosystematics Research Institute, Research Branch, Canada Department of Agriculture Publication 1576: 1-241.

Bright, D. E., AND G. O. Poinar, JR. 1994. Scolytidae and Platypodidae (Coleoptera) from Dominican Republic amber. Annals of the Entomological Society of America 87: 170-194.

BRIGHT, D. E., AND M. W. STOCK. 1982. Taxonomy and geographic variation. In J. B. Mitton and K. B. Sturgeon [eds.], Bark beetles in North American conifers: a system for the study of evolutionary biology, 46-73. University of Texas Press, Austin, Texas, USA.

BRongNiaRT, C. 1877. Perforations observées dans deux morceaux de bois fossile. Annales de la Société Entomologique de France (Fifth Series) 7: 215-220.

Brooks, D. R., AND C. MitTer. 1984. Analytical approaches to studying coevolution. In Q. Wheeler and M. Blackwell [eds.], Fungus-insect relationships, 42-53. Columbia University Press, New York, New York, USA.

Browne, F. G. 1961. The biology of Malayan Scolytidae and Platypodidae. Malayan Forest Records 22.

Chamberlin, W. J. 1939. The bark and timber beetles of North America north of Mexico. Oregon State College Cooperative Association, Corvallis, Oregon, USA.

Chamberlin, W. J. 1958. The Scolytoidea of the Northwest. Oregon State Monographs, Studies in Entomology 2.

Chase, M. W., ET AL. 1993. Phylogenetics of seed plants: an analysis of nucleotide sequences from the plastid gene $r b c \mathrm{~L}$. Annals of the Missouri Botanical Garden 80: 528-580.

Chaw, S.-M., A. Zharkikh, H.-M. Sung, T.-C. LAN, AND W.-H. Li. 1997. Molecular phylogeny of extant gymnosperms and seed plant evolution: analysis of nuclear 18S rRNA sequences. Molecular Biology and Evolution 14: 56-68.

Сноo, H. Y. 1983. Taxonomic studies on the Platypodidae and Scolytidae (Coleoptera) from Korea. Ph.D. dissertation, Seoul National University, Seoul, Korea.

Cichan, M. A., And T. N. TAYlor. 1982. Wood-borings in Premnoxylon: plant-animal interactions in the Carboniferous. Palaeogeography, $\mathrm{Pa}$ laeoclimatology, Palaeoecology 39: 123-127.

CoOK, S. P., AND F. P. HAIN. 1988. Wound response of loblolly and shortleaf pine attacked or reattacked by Dendroctonus frontalis Zimmermann (Coleoptera: Scolytidae) or its fungal associate, Ceratocystis minor (Hedgecock) Hunt. Canadian Journal of Forestry Research 18: 33-37.

Crowson, R. A. 1981. The biology of the Coleoptera. Academic Press, London, UK.

EberLe, J. J., AND J. C. Storer. 1999. Northernmost record of brontotheres, Axel Heiberg Island, Canada-implications for age of the Buchanan Lake Formation and brontothere paleobiology. Journal of Paleontology 73: 979-983.

Elias, S. A. 1985. Paleoenvironmental interpretations of Holocene insect fossil assemblages from four high-altitude sites in the Front Range, Colorado, U.S.A. Arctic and Alpine Research 17: 31-48.

Falder, A. B., G. W. Rothwell, G. Mapes, R. H. Mapes, and L. R. DoGUZHAEVA. 1999. Pitystrobus milleri sp. nov., a pinaceous cone from the Lower Cretaceous (Aptian) of southwestern Russia. Review of Palaeobotany and Palynology 103: 253-261.

FARJON, A. 1990. Pinaceae: drawings and descriptions of the genera Abies, Cedrus, Pseudolarix, Keteleeria, Nothotsuga, Tsuga, Cathaya, Pseudotsuga, Larix and Picea. Regnum Vegetabile 121: 1-330.

FrankIS, M. P. 1989. Generic inter-relationships in Pinaceae. Notes from the Royal Botanical Garden, Edinburgh 45: 527-548.

FURNISS, R. L. 1976. Controlled breeding comparative anatomy and bionomics of Dendroctonus simplex LeConte and Dendroctonus pseudotsugae Hopkins (Coleoptera: Scolytidae). University of Idaho Department of Entomology, Anniversary Publication 15: 109-120.

Furniss, R. L., AND V. M. CAROLIN. 1977. Western forest insects. United States Department of Agriculture Miscellaneous Publication 1339.

Futuyma, D. J., AND G. MoReno. 1988. The evolution of ecological specialization. Annual Review of Ecology and Systematics 19: 207-233. 
Genise, J. F., AND P. L. Hazeldine. 1995. A new insect trace fossil in Jurassic wood from Patagonia, Argentina. Ichnos 4: 1-5.

Goth, K., AND V. WILDE. 1992. Fraßspuren in permischen Hölzern aus Wetterau. Senckenbergiana Lethaea 72: 1-6.

GOWER, S. T., AND J. H. RichaRdS. 1990. Larches: deciduous conifers in an evergreen world. Bioscience 40: 818-826.

Gradstein, F., And J. OGg. 1996. A Phanerozoic time scale. Episodes 19: $3-5$.

Greenwood, D. R., And J. F. BAsinger. 1994. The paleoecology of highlatitude Eocene swamp forests from Axel Heiberg Island, Canadian High Arctic. Review of Palaeobotany and Palynology 81: 83-97.

GreENwOOD, D. R., AND S. L. WING. 1995. Eocene continental climates and latitudinal temperature gradients. Geology 23: 1044-1048.

Grimaldi, D. A. 1996. Amber: window to the past. Harry Abrams, New York, New York, USA.

Guo, S.-X. 1991. A Miocene trace fossil of insect from Shanwang Formation in Linqu, Shandong. Acta Palaeontologica Sinica 30: 739-742 (in Chinese).

HAGEDORN, M. 1906. Borkenkäfer des baltischen Bernsteins. Schriften der Physikalisch-Ökonomischen Gesellschaft zu Königsberg im Prussia 47: 115-121.

HAGEdoRN, M. 1907a. Kopalborkenkäfer. Verhandlungen des Vereins für Naturwissenschaftlich Unterhaltungen zu Hamburg im Prussia 13: 109112.

Hagedorn, M. 1907b. Fossile Borkenkäfer. Deutsche Entomologische Zeitschrift 1907: 259-261.

Harborne, J. B. 1972. Phytochemical methods. Chapman and Hall, London, UK.

Harrison, J. C., U. Mayr, D. H. McNeil, D. J. McIntyre, J. J. Eberle, C. R. Harrington, J. A. Chalmers, G. Dam, and H. NøHr-Hansen. 1999. Correlation of Cenozoic sequences of the Canadian Arctic region and Greenland; implications for the tectonic history of northern North America. Bulletin of Canadian Petroleum Geologists 47: 223-254.

HART, J. 1987. A cladistic analysis of conifers: preliminary results. Journal of the Arnold Arboretum 68: 269-307.

Hopkins, A. D. 1900. American fossil Coleoptera referred to the Scolytidae. Psyche 9: 64-67.

Hopkins, A. D. 1901. Insect enemies of the spruce in the Northeast. United States Department of Agriculture Division of Entomology Bulletin 28: 180.

HopkINS, A. D. 1909a. Contributions toward a monograph of the scolytid beetles. I. The Genus Dendroctonus. United States Department of Agriculture Bureau of Entomology Technical Series 17.

Hopkins, A. D. 1909b. Practical information on the scolytid beetles of North American forests. I. Barkbeetles of the genus Dendroctonus. United States Department of Agriculture Bureau of Entomology Bulletin 83.

Hopkins, A. D. 1911. Contributions toward a monograph of the bark-weevils of the genus Pissodes. United States Department of Agriculture Bureau of Entomology Technical Series 20.

Jagels, R. B., B. A. LePAge, And M. Jiang. 2001. Definitive identification of Larix (Pinaceae) wood based on anatomy from the middle Eocene, Axel Heiberg Island, Canadian High Arctic. International Association of Wood Anatomists Journal 22: 73-83.

JARZEMBowski, E. A. 1984. Early Cretaceous insects from southern England. Modern Geology 9: 71-94.

JARZEMbowski, E. A. 1990. A boring beetle from the Wealden of the Weald. In A. J. Boucot [ed.], Evolutionary paleobiology of behavior and coevolution, 373-376. Elsevier, Amsterdam, The Netherlands.

JERMY, T. 1984. Evolution of insect/host plant relationships. American Naturalist 124: 609-630.

Johnson, W. T., AND H. H. LyON. 1991. Insects that feed on trees and shrubs. 2nd revised edition. Cornell University Press, Ithaca, New York, USA.

KABE, M. 1954. Illustrations of galleries of bark beetles. Part 1 (Scolytidae and Platypodidae). Maebashi Regional Forest Office, Maebashi, Japan.

KARPINSKI, J. 1962. Odlew zerowisk kopalnego chrzascza z rodziny Scolytidae z piaskowca Oligomiocenskiego w Osieczowie (Dolny Slask). Prace Instiytut Geologiczny 30: 235-236 (in Polish).

KeEn, F. P. 1952. Insect enemies of western forests. United States Department of Agriculture Miscellaneous Publication 273.

Kelley, S. T., AND B. D. FARrell. 1998. Is specialization a dead end? The phylogeny of host use in Dendroctonus bark beetles (Scolytidae). Evolution 52: 1731-1743.

Krzeminska, E., J.-P. Haenni, W. Krzeminski, and C. Dufour. 1992. Les fantomes de l'ambre: insectes fossiles dans l'ambre de la Baltique. Musée d'Historie Naturelle de Neuchâtel, Neuchâtel, Switzerland.

Kurentzov, A. I., AND D. G. KonONOV. 1966. New species of bark beetles (Ipidae, Coleoptera). In New species in the fauna of Siberia and adjacent regions, 29-33. Institute of Biology, Siberian Branch, USSR Academy of Sciences, Vladivostok, Primorsk, Russia (in Russian).

Kuschel, G., R. A. B. Leschen, And E. C. Zimmerman. 2000. Platypodidae under scrutiny. Invertebrate Taxonomy 14: 771-805.

LABANDEIRA, C. C. 1997. Insect mouthparts: ascertaining the paleobiology of insect feeding strategies. Annual Review of Ecology and Systematics 28: 153-193.

LABANDEIRA, C. C. 1998a. The early ecologic history of plant-insect associations. Annual Review of Earth and Planetary Science 26: 329-377.

LABANDEIRA, C. C. 1998b. The role of insects in late Jurassic to middle Cretaceous ecosystems. In S. G. Lucas, J. I. Kirkland, and J. W. Estep [eds.], Lower and middle Cretaceous terrestrial ecosystems. New Mexico Museum of Natural History and Science Bulletin 14: 105-124.

LABANDEIRA, C. C. 2002. The history of associations between plants and animals. In C. Herrera and O. Pellmyr [eds.], Plant-animal interactions. Blackwell Science, Oxford, UK, in press.

Labandeira, C. C., D. L. Dilcher, D. R. Davis, and D. L. Wagner. 1994. 97 million years of angiosperm-insect association: paleobiological insights into the meaning of coevolution. Proceedings of the National Academy of Sciences USA 91: 12278-12282.

Labandeira, C. C., T. L. Phillips, and R. A. Norton. 1997. Oribatid mites and the decomposition of plant tissues in Paleozoic coal-swamp forests. Palaios 12: 319-353.

LANGOR, D. W., AND A. G. RASKE. 1987a. Emergence, host attacks, and overwintering behavior of the eastern larch beetle, Dendroctonus simplex LeConte (Coleoptera: Scolytidae) in Newfoundland. Canadian Entomologist 119: 975-983.

LANGOR, D. W., AND A. G. RASKe. 1987b. Reproduction and development of the Eastern larch beetle, Dendroctonus simplex LeConte (Coleoptera: Scolytidae), in Newfoundland. Canadian Entomologist 119: 985-992.

LANIER, G. N. 1981. Cytotaxonomy of Dendroctonus. In M. W. Stock [ed.], Applications of genetics and cytology in insect systematics and evolution, 33-66. University of Idaho Wildlife and Range Experimental Station, Moscow, Idaho, USA.

LANIER, G. N., AND W. E. Burkholder. 1974. Pheromones in speciation of Coleoptera. In M. C. Birch [ed.], Pheromones, 161-189. North Holland, Amsterdam, The Netherlands.

Larew, H. G. 1986. The fossil gall record: a brief summary. Proceedings of the Entomological Society of Washington 88: 385-388.

LARSSON, S. G. 1978. Baltic amber-a palaeobiological study. Entomonograph 1: 1-192.

LePage, B. A. 2001. New species of Picea A. Dietrich (Pinaceae) from the middle Eocene of Axel Heiberg Island, Arctic Canada. Botanical Journal of the Linnean Society 135: 137-167.

LePage, B. A., And J. F. Basinger. 1989. Early Tertiary Larix from the Canadian High Arctic. Musk-Ox 37: 103-109.

LePage, B. A., And J. F. Basinger. 1991a. Early Tertiary Larix from the Buchanan Lake Formation, Canadian Arctic Archipelago, and a consideration of the phytogeography of the genus. Geological Survey of Canada Bulletin 403: 67-82.

LePage, B. A., And J. F. Basinger. 1991b. A new species of Larix (Pinaceae) from the early Tertiary of Axel Heiberg Island, Arctic Canada. Review of Palaeobotany and Palynology 70: 89-111.

LePage, B. A., And J. F. BAsinger. 1995a. The evolutionary history of the genus Larix (Pinaceae). United States Department of Agriculture Forest Service, Intermountain Research Station, General Technical Report GTR-INT-319:19-29.

LePage, B. A., And J. F. BAsinger. 1995b. Evolutionary history of the genus Pseudolarix Gordon (Pinaceae). International Journal of Plant Sciences 156: 910-950.

LiNCK, O. 1949. Fossile Bohrgänge (Anobichnium simile n. g. n.sp.) an einem Keuperholz. Neues Jahrbuch für Mineralogie, Geologie und Paläontologie Monatschefte 1949B: 180-185.

MabBerley, D. J. 1993. The plant-book: a portable dictionary of the higher plants. Cambridge University Press, Cambridge, UK.

Massey, C. L., AND N. D. Wygant. 1954. Biology and control of the Engelmann spruce beetle in Colorado. United States Department of Agriculture Forest Service Circular 944: 1-35.

MCInTyre, D. J. 1991. Pollen and spore flora of an Eocene forest, eastern 
Axel Heiberg Island, N.W.T. Geological Survey of Canada Bulletin 403: 83-97.

Miller, C. N. 1977. Mesozoic conifers. Botanical Review 43: 217-280.

Miller, C. N. 1989. A new species of Picea based on silicified seed cones from the Oligocene of Washington. American Journal of Botany 76: 747754.

OpleR, P. A. 1973. Fossil lepidopterous leaf mines demonstrate the age of some insect-plant relationships. Science 179: 1321-1323.

Péwé, T. L., G. W. Berger, J. A. Westgate, P. M. Brown, and S. W. LEAvitT. 1997. Eva interglaciation Forest Bed, unglaciated east-central Alaska: global warming 125,000 years ago. Geological Society of America Special Paper 319: 1-54.

Peyerimhoff, P. 1919. Notes sur la biologie de quelques Coléoptères phytophages du Nord Africain. III. Annales de la Société Entomologique de France 1919: 169-258.

POINAR, G. O., JR. 1992. Life in amber. Stanford University Press, Stanford, California, USA.

Ponomarenko, A. G. 1995. The geological history of beetles. In J. Pakaluk and S. A. Slipinski [eds.], Biology, phylogeny, and classification of Coleoptera: papers celebrating the 80th birthday of Roy A. Crowson, 155171. Museum and Institute of Zoology, Warsaw, Poland.

Price, R. A., A. Liston, and S. H. Strauss. 1998. Phylogeny and systematics of Pinus. In D. M. Richardson [ed.], Biology and biogeography of Pinus, 49-68. Cambridge University Press, Cambridge, UK.

Price, R. A., J. Olsen-Stojkovitch, And J. M. Lowenstein. 1987. Relationships among the genera of Pinaceae: an immunological comparison. Systematic Botany 12: 91-97.

RADWANSKI, A. 1977. Present-day types of trace in the Neogene sequence: their problems of nomenclature and preservation. In T. P. Crimes and J. C. Harper [eds.], Trace fossils 2, 227-264. Seel House Press, Liverpool, UK.

Renwick, J. A. A., AND J. P. Vité. 1969. Bark beetle attractants: mechanism of colonization by Dendroctonus frontalis. Nature 224: 1222-1223.

Renwick, J. A. A., AND J. P. Vité. 1970. Systems of chemical communication in Dendroctonus. Contributions from the Boyce Thompson Institute for Plant Research 24: 283-292.

RicKETTS, B. D. 1986. New formations in the Eureka Sound Group, Canadian Arctic Islands. Geological Survey of Canada Paper 86-1B: 363-374.

RicKETTS, B. D. 1991. Sedimentation, Eurekan tectonism and the fossil forest succession on eastern Axel Heiberg Island, Canadian Arctic Archipelago. Geological Survey of Canada Bulletin 403: 1-27.

RicKeTTS, B. D. 1994. Basin analysis, Eureka Sound Group, Axel Heiberg and Ellesmere Islands, Canadian Arctic Archipelago. Memoirs of the Geological Survey of Canada 439: 1-119.

RicketTs, B. D., AND D. J. McInTYRE. 1986. The Eureka Sound Group of eastern Axel Heiberg Island: new data on the Eurekan Orogeny. Geological Survey of Canada Paper 86-1B: 405-410.

Rose, A. H., AND O. H. LINDQUIST. 1992. Insects of eastern larch, cedar and juniper. Forestry Canada, Forestry Technical Report 28.

RozHKov, A. S. 1970. Pests of Siberian Larch. Translated by S. Nemchonok, from the Russian. Israel Program for Scientific Translations, Jerusalem, Israel.

RudinSKY, J. A. 1963. Response of Dendroctonus pseudotsugae Hopkins to volatile attractants. Contributions from the Boyce Thompson Institute of Plant Research 22: 22-38.

Rudinsky, J. A. 1968. Pheromone-mask by the female Dendroctonus pseudotsugae Hopk., an attraction regulator (Coleoptera: Scolytidae). PanPacific Entomologist 44: 248-250.

SCHEDL, K. E. 1947. Die Borkenkäfer des baltischen Bernsteins. 58. Beitrag zur Morphologie und Systematik der Scolytidae und Platypodidae. Zentralblatt für das Gesamigebiet der Entomologie 2: 12-45.

Schmid, J. M., AND R. H. Frye. 1977. Spruce beetle in the Rockies. United States Department of Agriculture Forest Service General Technical Report RM-49:1-38.

SCHOONHOVEn, L. M., T. JERMY, AND J. J. A. VAN LOON. 1998. Insect-plant biology: from physiology to evolution. Chapman and Hall, London, UK.

Scott, A. C., J. Stephenson, And W. C. Chaloner. 1992. Interaction and coevolution of plants and arthropods during the Palaeozoic and Mesozoic. Philosophical Transactions of the Royal Society of London (B) 335: $129-165$.

SCUDDER, S. H. 1876. Fossil Coleoptera from the Rocky Mountain Tertiaries. Bulletin of the United States Geological and Geographical Survey of the Territories 2: 77-87.
SCUdDER, S. H. 1878. The fossil insects of the Green River shales. Bulletin of the United States Geological and Geographical Survey of the Territories 4: 747-776.

SCUDDER, S. H. 1893. Tertiary rhynchophorous Coleoptera of the United States. Monographs of the United States Geological Survey 21: 1-206.

Sequeira, A. S., B. B. Normark, AND B. D. Farrell. 2000. Evolutionary assembly of the conifer fauna: distinguishing ancient from recent associations in bark beetles. Proceedings of the Royal Society of London B 267: 2359-2366.

Sмith, D. M. 2000. Beetle taphonomy in a Recent ephemeral lake southeastern Arizona. Palaios 15: 152-160.

SpAHR, U. 1981. Systematischer Katalog der bernstein- und kopal-Käfer. Stuttgarter Beiträge zur Naturkunde (B) 80: 1-107.

STARK, R. W. 1982. Generalized ecology and life cycle of bark beetles. In J. B. Mitton and K. B. Sturgeon [eds.], Bark beetles in North American conifers: a system for the study of evolutionary biology, 21-45. University of Texas Press, Austin, Texas, USA.

Stefanovic, S., M. Jager, J. Deutsche, B. Broutin, and M. Masselot. 1998. Phylogenetic relationships of conifers inferred from partial $28 \mathrm{~S}$ rRNA gene sequences. American Journal of Botany 85: 688-697.

STEPHENSON, J. 1991. Evidence of plant/insect interactions in the Late Cretaceous and early Tertiary. Ph.D. dissertation, University of London, London, UK.

Sturgeon, K. B., AND J. B. Mitton. 1982. Evolution of bark beetle communities. In J. B. Mitton and K. B. Sturgeon [eds.], Bark beetles in North American conifers: a system for the study of evolutionary biology, 350384. University of Texas Press, Austin, Texas, USA.

TAYLOR, T. N., AND E. L. TAYLOR. 1993. The biology and evolution of fossil plants. Prentice Hall, Englewood Cliffs, New Jersey, USA.

Thompson, J. N. 1994. The coevolutionary process. University of Chicago Press, Chicago, Illinois, USA.

Tidwell, W. D., And S. R. Ash. 1990. On the Upper Jurassic stem Hermanophyton and its species from Colorado and Utah, USA. Palaeontographica (Abh. B) 218: 77-92.

TiLTON, D. L. 1977. Seasonal growth and foliar nutrients of Larix larcina in three wetland ecosystems. Canadian Journal of Botany 55: 1291-1298.

TRÄGÅRDH, I. 1930. Studies on the galleries of the bark-beetles. Bulletin of Entomological Research 21: 469-480.

Tsai, P.-H., AND C.-L. Li. 1959. First report of Scolytidae in northern China. Collected Papers in Entomology 1959: 73-117. Science Press, Beijing (in Chinese).

Tsumura, Y., K. Yoshimura, N. Tomaru, And K. OHba. 1995. Molecular phylogeny of conifers using RFLP analysis of PCR-amplified specific chloroplast genes. Theoretical and Applied Genetics 91: 1222-1236.

Wainhouse, D., AND P. Beech-Garwood. 1994. Growth and survival of Dendroctonus micans larvae on six species of conifer. Journal of Applied Entomology 117: 393-399.

Walker, M. V. 1938. Evidence of Triassic insects in the Petrified Forest National Monument, Arizona. Proceedings of the United States National Museum 85: 137-141, pls. 1-4.

Weaver, L., S. Mcloughlin, and A. N. Drinnan. 1997. Fossil woods from the Upper Permian Bainmedart Coal Measures, northern Prince Charles Mountains, East Antarctica. Journal of Australian Geology and Geophysics 16: 655-676.

Werner, R. A. 1986. The eastern larch beetle in Alaska. United States Department of Agriculture Forest Service Research Paper PNW 356:1-13.

WERNER, R. A., B. H. BAKER, AND P. A. RUSH. 1977. The spruce beetle in white spruce forests of Alaska. United States Department of Agriculture Forest Service General Technical Report PNW-61:1-13.

Werner, R. A., M. M. FuRniss, L. C. YARGER, AND T. WARD. 1981. Effects on eastern larch beetle, Dendroctonus simplex, of its natural attractant and synthetic pheromones in Alaska. United States Department of Agriculture Forest Service Research Note PNW 371:1-7.

Wickham, H. F. 1913. Fossil Coleoptera from the Wilson Ranch near Florissant, Colorado. Bulletin of the Laboratories of Natural History of the State University of Iowa 6: 3-29.

Wickham, H. F. 1916. New fossil Coleoptera from the Florissant beds. Bulletin of the Laboratories of Natural History of the State University of Iowa 6: 18-19.

Wilf, P., AND C. C. LABANDEIRA. 1999. Response of plant-insect associations to Paleocene-Eocene warming. Science 284: 2153-2156.

Wilf, P., C. C. Labandeira, W. J. Kress, C. L. Staines, D. M. Windsor, A. L. Allen, And K. R. Johnson. 2000. Timing the radiations of leaf 
beetles: hispines on gingers from latest Cretaceous to Recent. Science 289: 291-294.

WiLson, L. F. 1977. A guide to insect injury of conifers in the Lake States. United States Department of Agriculture Forest Service Agriculture Handbook 501.

Wolfe, J. A. 1980. Tertiary climates and floristic relationships at high latitudes in the Northern Hemisphere. Palaeogeography, Palaeoclimatology, Palaeoecology 30: 313-323.

Wood, S. L. 1963. A revision of the bark-beetle genus Dendroctonus Erichson (Coleoptera: Scolytidae). Great Basin Naturalist 23: 1-117.

Wood, S. L. 1973. On the taxonomic status of Platypodidae and Scolytidae (Coleoptera). Great Basin Naturalist 33: 77-90.

Wood, S. L. 1982. The bark and ambrosia beetles of North and Central America (Coleoptera: Scolytidae), a taxonomic monograph. Great Basin Naturalist Memoirs 6.

Wood, S. L. 1986. A reclassification of the genera of Scolytidae (Coleoptera). Great Basin Naturalist Memoirs 10: 1-126.

Wood, S. L., AND D. E. BRIGHT, JR. 1992. A catalog of Scolytidae and
Platypodidae (Coleoptera), part 2, taxonomic index. Great Basin Naturalist Memoirs 13B: 835-1553.

Xiao-Quan, W., H. Ying, D. Zhang-Rong, and H. De-Yuan. 1997. Phylogeny of the Pinaceae evidenced by molecular biology. Acta Phytotaxonomica Sinica 35: 97-106.

YanovskiJ, V. M. 1999. Annotated list of scolytids (Coleoptera, Scolytidae) of North Asia. Entomological Review 79: 493-522.

YIN, H.-F., F. S. HuANG, AND S.-L. LI. 1984. Economic insect fauna of China. Fascicle 19. Coleoptera: Scolytidae. Science Press, Beijing, China.

Zavada, M. S., AND M. T. Mentis. 1992. Plant-animal interaction: the effect of Permian megaherbivores on the glossopterid flora. American Midland Naturalist 127: 1-12.

Zhou, Z., AND B. ZHANG. 1989. A sideritic Protocupressinoxylon with insect borings and frass from the Middle Jurassic, Henan, China. Review of Palaeobotany and Palynology 59: 133-143.

ZúNiga, G., G. Mendoza Correa, R. Cisneros, and Y. Salinas-Moreno. 1999. Zonas de sobreposición en las áreas de distribución geografica de las especies Méxicanas de Dendroctonus Erichson (Coleoptera: Scolytidae) y sus impliciones ecológico-evolutivas. Acta Zoologica Mexicana 77: 1-22. 